$\begin{array}{ll}\text { Abstracta Iranica } & \begin{array}{l}\text { Abstracta Iranica } \\ \text { Revue bibliographique pour le domaine irano-aryen }\end{array} \\ & \text { Volume } 25 \mid \mathbf{2 0 0 4} \\ \text { Comptes rendus des publications de } \mathbf{2 0 0 2}\end{array}$

\title{
The Shiite Movement in Iraq. London, Saqibooks, 2003, 391 p.
}

Tchanguiz Pahlavan

\section{(2) OpenEdition}

1 Journals

Édition électronique

URL : http://journals.openedition.org/abstractairanica/4856

DOI : 10.4000/abstractairanica.4856

ISSN : 1961-960X

Éditeur :

CNRS (UMR 7528 Mondes iraniens et indiens), Éditions de l'IFRI

\section{Édition imprimée}

Date de publication : 15 mai 2004

ISSN : 0240-8910

\section{Référence électronique}

Tchanguiz Pahlavan, «The Shiite Movement in Iraq. London, Saqibooks, 2003, 391 p. », Abstracta Iranica [En ligne], Volume 25 | 2004, document 243, mis en ligne le 15 mars 2006, consulté le 25 septembre 2020. URL : http://journals.openedition.org/abstractairanica/4856 ; DOI : https://doi.org/10.4000/ abstractairanica. 4856

Ce document a été généré automatiquement le 25 septembre 2020.

Tous droits réservés 


\title{
The Shiite Movement in Iraq. London, Saqibooks, 2003, 391 p.
}

\author{
Tchanguiz Pahlavan
}

1 This book is another contribution to questions related to the place and importance of Iraqi Shi'ism. Although it is a study of the Shi'ite movement in Iraq, at the same time it is one more contribution to a series of studies related to Shi' ism to help understand Shi'ite political movements in the contemporary world.

2 This is an informative and analytical book on Iraqi Shi'ism. The author tries to define Iraqi Shi'ism, its society, culture and politics, its institutions, financial system and authorities. Since the Iranian Revolution in 1979, there has been increasing focus and attention on the different Shi'ite communities, Shi'ite militant Islam and Shi'ism in general. In this very book the author, in his own words, attempts to fill the gap in our understanding of the social origins, actors and ideology of Shi'ite Islamism in Iraq. According to him, the rise of modern Shi'ite Islamic militancy in Iraq can be dated to the late 1950s, after the demise of the monarchy in July 1958, although its roots go back much further. The author's main interest concentrates on the modern history of the Shi'ite movement in Iraq. Even in his Introduction, the author deals with the recent developments after US-British occupation of Iraq (2003) and the place of Iraqi Shi'ism.

3 The book is divided into five parts. In Part One, the author deals with problems related to State, Nation and Islamism. In Part Two, we have a discussion about Genesis and Mutation. Here he describes the Shi'ite political organisations. In Part Three, he pays attention to Shi'ite cultural spaces, especially to Marjaism and popular rituals. Shi'ite Islamism and Bath rule in Iraq is discussed in Part Four, in which we see how a peaceful movement turns into a militant one. In Part Five, there is a discussion of the political theory and socio-economic doctrines of Iraqi Shi'ism. 
INDEX

Thèmes : 7. Islam

\section{AUTEURS}

TCHANGUIZ PAHLAVAN

Münster 